NBER WORKING PAPER SERIES

\title{
HOW HAS CEO TURNOVER CHANGED? INCREASINGLY PERFORMANCE SENSITIVE BOARDS AND INCREASINGLY UNEASY CEOS
}

\author{
Steven N. Kaplan \\ Bernadette A. Minton \\ Working Paper 12465 \\ http://www.nber.org/papers/w12465
NATIONAL BUREAU OF ECONOMIC RESEARCH 1050 Massachusetts Avenue
Cambridge, MA 02138
August 2006

This research has been supported by the Center for Research in Security Prices, by the Lynde and Harry Bradley Foundation and the Olin Foundation through grants to the Center for the Study of the Economy and the State, and the Dice Center for Research in Financial Economics. We thank Stuart Gillan, Chester Spatt, and seminar participants at the NBER Corporate Governance Summer Institute for helpful comments. The views expressed herein are those of the author(s) and do not necessarily reflect the views of the National Bureau of Economic Research.

(C)2006 by Steven N. Kaplan and Bernadette A. Minton. All rights reserved. Short sections of text, not to exceed two paragraphs, may be quoted without explicit permission provided that full credit, including () notice, is given to the source. 
How Has CEO Turnover Changed? Increasingly Performance Sensitive Boards and Increasingly Uneasy CEOs

Steven N. Kaplan and Bernadette A. Minton

NBER Working Paper No. 12465

August 2006

JEL No. G3, L2

\begin{abstract}
$\underline{\text { ABSTRACT }}$
We study CEO turnover - both internal (board driven) and external (through takeover and bankruptcy) - from 1992 to 2005 for a sample of large U.S. companies. Annual CEO turnover is higher than that estimated in previous studies over earlier periods. Turnover is $14.9 \%$ from 1992 to 2005, implying an average tenure as CEO of less than seven years. In the more recent period since 1998, total CEO turnover increases to $16.5 \%$, implying an average tenure of just over six years. Internal turnover is significantly related to three components of firm performance - performance relative to industry, industry performance relative to the overall market, and the performance of the overall stock market. Also in the more recent period since 1998, the relation of internal turnover to performance is more strongly related to all three measures of performance in the contemporaneous year. External turnover is not significantly related to any of the measures of stock performance over the entire sample period, nor over the two sub-periods. We discuss the implications of these findings for various issues in corporate governance.
\end{abstract}

Steven N. Kaplan

Graduate School of Business

The University of Chicago

5807 South Woodlawn Avenue

Chicago, IL 60637

and NBER

steven.kaplan@gsb.uchicago.edu 


\section{Introduction}

In the last several years, corporate governance in the United States has come under great scrutiny, if not attack. The corporate governance scandals early in this decade led to the Sarbanes Oxley legislation. Since the legislation, the criticism of corporate governance has continued. CEOs are routinely criticized for being overpaid. Boards of directors are routinely criticized as cronies of those overpaid CEOs. Jensen, Murphy and Wruck (2004) document the increase in CEO pay since the 1970s. Bebchuk and Fried (2003) and Bebchuk and Grinstein (2005) document a substantial increase in CEO pay accelerated after 1995. All three papers criticize boards of directors for the increases in CEO pay and for not doing a good job monitoring the pay practices and CEOs.

While a great deal of work has focused on changes in CEO pay, recent changes in CEO turnover and board behavior have received little attention. Earlier work and casual empiricism suggest that the CEO's job has become riskier over time. Khurana (2003) reports that CEO turnover increased in the 1990s relative to the 1970s and 1980s. Murphy and Zabonjik (2004) and Jensen et al. (2004) also report that turnover has increased in the 1990s, although the magnitude they report is quite small - from $10 \%$ per year in the 1970 s and 1980 s to $11 \%$ in the 1990s. The samples in these papers do not go beyond the year 2000 so they are unable to consider the period in which corporate governance and CEO performance and pay have been subject to intense scrutiny.

In this paper, we study CEO turnover from 1992 to 2005 for a sample of large U.S. companies. We consider turnover that occurs through takeover and bankruptcy as well as turnover in ongoing companies. When takeovers and bankruptcies are taken into consideration, the job of CEO in large U.S. companies appears more precarious than before, particularly after 
1997. Annual CEO turnover is $14.9 \%$ from 1992 to 2005 , implying an average tenure as CEO of less than seven years. In the more recent period since 1998, total CEO turnover increases to $16.5 \%$, implying an average CEO turnover of just over six years. Internal or board driven turnover also rises substantially, increasing from $10.3 \%$ in the first part of the sample to $12.8 \%$ in the latter part of the sample. Looked at another way, only 35\% of CEOs in place in 1992 remained CEO in 1997, while only 24\% of CEOs in place in 1998 remained CEO in 2003.

We then look at how turnover varies with firm performance. Previous work suggests a modest relation between internal (board initiated) turnover and firm performance. (See Murphy (1999) and Jensen et al. (2004)). We find a stronger and significant relation between internal turnover and firm performance. Interestingly, internal turnover is related to three different components of total firm performance. I.e., turnover is sensitive to the performance of the firm relative to the industry, the performance of the industry relative to the stock market, and the performance of the overall stock market. ${ }^{1}$ The sensitivity to a one standard deviation difference in each of these measures is economically meaningful.

Further, internal turnover after 1997 is more strongly related to all three measures of performance. In fact, the sensitivity to performance appears to be greater than that in any of the periods between 1970 and 1995 studied in Murphy (1999). Ironically, it appears that during the period in which boards have been heavily criticized, boards have become increasingly sensitive to firm performance and have acted more quickly and decisively.

External turnover - turnover primarily related to acquisitions - is not significantly related to any of the stock performance measures, nor do we observe any difference between the two sub-periods as we do for internal turnover.

Our results suggest a number of implications.

\footnotetext{
${ }^{1}$ Jenter and Kanaan (2006) obtain similar results which we discuss below.
} 
First, the results suggest an evolving role for boards. In a sample from the 1980s, Morck, Shleifer and Vishny (1989) find that internal turnover is related to industry-adjusted performance while external turnover from hostile takeovers is related to industry performance. They interpret this as indicating boards respond well to poor performance relative to the industry, but do not respond well to poor industry performance. The external takeover market becomes active in reaction to poor industry performance and a need for restructuring.

Our results suggest that boards now respond not only to poor performance relative to the industry, but also to poor industry performance and to poor market performance. To the extent that internal turnover has increased, boards also appear to monitor more frequently or aggressively. One interpretation of these results is that boards - possibly encouraged by large shareholders - perform both the role they performed in the 1980s and the role that hostile takeovers played then.

It is worth repeating that the results indicate that boards do not index CEO turnover to the industry or the market. This is noteworthy in light of criticisms of boards for not indexing CEO pay to the industry or the market. Bebchuk and Fried (2003) interpret the lack of indexing of pay as a failure of governance. Our results on turnover in conjunction with those in Morck et al. (1989) for the earlier period provide an alternative explanation. When an industry or the overall economy performs poorly, it is sometimes efficient for the board to bring on a new CEO to respond to the new industry or market conditions.

Second, the results indicate that the CEO job is more precarious than has been previously recognized. When external takeovers are included, the average tenure of a CEO has declined to as little as six years for the recent 1998 to 2005 period. The recent tenures are substantially shorter than those reported in previous work for the 1970s, 1980s, and 1990s. For individual 
CEOs, the shorter expected tenure likely offsets some of the benefit of the increase in CEO pay over this period.

Third, the shorter expected CEO tenures and sensitivity of those tenures to stock performance have implications for the measurement of CEO pay. The shorter expected tenures suggest that the estimates of CEO pay used in most compensation studies are overstated. Most such studies use Standard and Poor's ExecuComp data. ExecuComp estimates the value of options grants using Black-Scholes. While option grants typically have a ten-year life, ExecuComp uses a seven-year life because "executives rarely wait until the expiration date to exercise their options." This adjustment assumes that CEOs will remain with the company for at least seven years. If a CEO has an expected initial tenure of six years, the ExecuComp assumption will tend to overstate the value of option grants every year of the CEO's tenure with the overstatement increasing each year. ${ }^{2}$ ExecuComp also values restricted stock grants as fully vested when, in fact, they usually vest over a period of time. This also will tend to overstate executive compensation.

The sensitivity of turnover to performance implies that the vesting and effective life of stock options are not independent of performance. The options of CEOs of companies that perform poorly will both have a shorter effective life and will be worth less. The Black-Scholes methodology does not take these correlations into account. This, in turn, implies that a proper valuation of stock options - e.g., using a binomial tree approach - would incorporate these correlations.

\footnotetext{
${ }^{2}$ This assumes that CEOs forfeit unvested options and / or must exercise vested options when they leave the company. Yermack (2006) finds that this tends to be the default policy and companies deviate from those policies in $16 \%$ of the internal turnovers he studies. We discuss this in more detail later in the paper.
} 
Finally, shorter CEO tenures, the greater sensitivity to stock performance, as well as higher CEO pay may have created a greater incentive for CEOs to engage in earnings management or manipulation.

This paper was written contemporaneously with Jenter and Kanaan (2005) who study related issues in a sample of CEO turnover from 1993 to 2001. They focus on forced CEO turnover, rather than all CEO turnover. Forced turnovers represent somewhere between $15 \%$ and $25 \%$ of total internal turnovers. As we do for forced and unforced turnover, they find that forced CEO turnover is significantly related to industry-adjusted, industry, and market returns. They focus most of their paper on verifying this effect for forced turnover and explaining why boards might behave this way. They also study a larger sample of firms, but over a shorter time period. Unlike us, they do not focus on the level of total turnover, the annual variation in that turnover, and do not consider external turnovers. Given their shorter sample, they also do not consider how turnover behavior changes from the early to later part of the sample.

Our paper also is related to that of Mikkelson and Partch (1997) who compare complete management turnover in US companies in two five-year periods - the active takeover market of 1984 - 1988 and the less active market of 1989-1993. In the active takeover period, they find that 39\% of firms experience CEO turnover and 23\% of firms experience complete management turnover; in the less active period, $34 \%$ of firms experience CEO turnover while $16 \%$ of firms experience complete management turnover. They find that the decline in turnover frequency is more pronounced among poorly performing firms. They argue that the activity of the external takeover market affects the "intensity of management discipline." Our results suggest that the intensity of management discipline has increased substantially since the end of their sample period, and likely exceeds the intensity of the active takeover period. 
The paper proceeds as follows. Section II describes our sample. Section III presents the results for turnover levels. Section IV presents the turnover-performance regressions. Section V summarizes and discusses the implications of these results.

\section{Sample and Data}

The sample of firms includes all Fortune 500 firms with data on both the Center for Research in Security Prices (CRSP) tapes and Compustat files (research and current files). The sample runs from fiscal-year end 1991 to fiscal-year-end 2005. We construct the sample using the annual Fortune 500 lists from 1992 to 2006. Each year, Fortune ranks firms based on sales at fiscal-year end and publishes the list in an April or May issue of the following year. For example, fiscal-year end 1991 rankings are published in an April or May 1992 issue. Table 1 provides summary statistics for the sample firms. Not surprisingly, the sample firms are large with mean (median) sales of $\$ 7.5$ billion ( $\$ 3.9$ billion). The number of observations increases substantially in 1994 because Fortune changed its criteria for inclusion, broadening the number of firms that could be included in the Fortune 500.

We follow the sample firms from the first year they appear on a Fortune list until the end of the sample period or until the firm exits the sample because of a merger, acquisition or delisting from a major stock exchange. We identify CEO turnovers using the Fortune 500 and Fortune 1000 lists, 10-K filings, proxy statements, Dun and Bradstreet's Million Dollar Directory, the Wall Street Journal and Lexis/Nexis business news searches. 


\section{Turnover Levels}

Turnover in a given fiscal year, T, means that the CEO in the spring of that year is no longer the CEO by the following spring. We measure turnover, therefore in the years 1992 to 2005. We consider two types of turnover. Standard or internal turnover is turnover that is associated with a company's board of directors. For standard turnover, a company remains publicly-listed over the course of the year, but the CEO in the spring is no longer the CEO the following spring. This is the turnover that is generally measured in studies of turnover. Nonstandard or external turnover is turnover due to a merger or bankruptcy / delisting. We also consider the CEO to have been turned over if his or her company is taken over by another company and he or she is not CEO of the combined company. We view this as an instance of turnover because in many mergers the former CEO leaves the combined company. In those instances in which the CEO former remains, the former CEO generally experiences a reduction in pay and power. Total turnover is the sum of internal and external turnover.

Table 2 presents the level of CEO turnover by year. Figure 1 presents this information graphically. There are three noteworthy patterns. First, total turnover levels are substantially higher than those typically reported. Overall turnover is $14.9 \%$ over the entire sample period implying an average CEO tenure of 6.7 years. This is substantially higher than that reported in Jensen, Murphy and Wruck (2004) and Murphy and Zabonjik (2004) who study a different sample of large firms (from the Forbes lists) over three decades from 1970 to 2000. They report turnover of $10.2 \%$ in the $1970 \mathrm{~s}, 10.0 \%$ in the $1980 \mathrm{~s}$, and $11.3 \%$ in the $1990 \mathrm{~s}$. All of these measures, however, are for standard or internal turnover. For our sample period of 1992 to 2005, we obtain a standard turnover of $11.8 \%$, similar to their results for the 1990 s. At $11.8 \%$, the 
estimated average CEO tenure is 8.5 years, roughly two years greater than the actual average tenure (that includes external takeover).

The second noteworthy pattern in table 2 is the time series variation in the levels of both total and internal turnover. Total turnover is as low as 6.4\% in 2003 (and only 8.6\% in 1994), and as high as $25.0 \%$ in 2000 (and 19.8\% in 1999).

Third, turnover increased significantly in the latter part of the sample. In the earlier period from 1992 to 1997 , CEO turnover is $12.7 \%$ per year implying an average tenure of 7.9 years. In the more recent period from 1998 to 2005, total CEO turnover increases to $16.5 \%$, implying an average CEO turnover of 6.1 years. Internal or board driven turnover also rises substantially, increasing from $10.3 \%$ in the first part of the sample to $12.8 \%$ in the latter part of the sample. The increase in turnover is driven by very high levels of turnover from 1998 to 2002 and in 2005.

It is natural to divide the sample period into pre-1998 and post-1997 because this break roughly coincides with the large increase in CEO pay described in Bebchuk and Grinstein (2005). ${ }^{3}$ The period in which CEO pay increased substantially coincides with a period in which CEO tenure decreases substantially. It is worth adding that the increased level of turnover began well before 2002 (when the Enron and Worldcom scandals became apparent and Sarbanes-Oxley was passed).

Table 3 presents the turnover data in a different way. We compare the fraction of the CEOs in 1992 who are no longer CEOs in 1997 to the fraction of CEOs who are CEOs in 1998 and no longer CEOs in 2003. The table shows that $65 \%$ of CEOs in 1992 were no longer CEOs

\footnotetext{
${ }^{3}$ We used the same 1997-1998 breakpoint in the previous version of the paper. Because that version that did not include 2005 turnover, the breakpoint represented roughly half of the sample.
} 
in 1997, while over 76\% of CEOs in 1998 were no longer CEOs by 2003. Again, this result suggests that the job of CEO has become increasingly precarious over the sample period.

The turnover also is substantially greater than that measured by Mikkelsen and Partch (1997) over two earlier five year periods. In the active takeover period from 1983 to 1988, they find that 39\% of firms experience CEO turnover (and 23\% of firms experience complete management turnover); in the less active period from 1989 to 1993, 34\% of firms experience CEO turnover (while 16\% of firms experience complete management turnover). Unfortunately, these results are not directly comparable because the sample in Mikkelsen and Partch consists of smaller firms.

\section{The Relation of Turnover and Performance}

\section{A. Internal Turnover}

We estimate probit regressions to examine the likelihood of internal CEO turnover. In all of the probit regressions, the dependent variable is equal to one if a CEO turns over and zero otherwise. The tables report the marginal changes in the probability of internal CEO turnover, implied by the probit coefficient estimates that result from a unit change in the explanatory variables. For indicator variables, the coefficient represents the change in the probability associated with moving the indicator from 0 to 1 . These marginal sensitivities, labeled " $\Delta$ Prob," are economically equivalent to coefficient estimates from ordinary least squares estimation. In the discussion below, we focus on the significance of these marginal effects.

In all of the probit regressions, three proxies are used to measure stock market performance. First, we measure market performance using the annual return on the S\&P 500 index. Second, relative industry performance is measured at the two-digit SIC code level and 
equals the difference between the return on the median firm in the industry and the return on the S\&P 500 index. Third, relative firm performance is measured as the industry-adjusted firm stock return, which is equal to the firm stock return minus the return for the median firm in the same two-digit SIC code. All returns are measured at calendar year-end.

In table 4, we report the results for two sets of probit regressions. In the first set of regressions, we include measures of stock market performance and an indicator variable equal to one if lagged CEO age is greater than or equal to 60 (CEO age dummy). In the second set of regressions, we add the change in ROA as a measure of operating performance. For the first set of regressions, we report the results for the full sample period and two sub-periods: 1992 to 1997 and 1998 to 2005 . For the second set of regressions, we report the results for the period 1992 to 2004 and two sub-periods: 1992 to 1997 and 1998 to 2004 (because of data availability for change in ROA).

Table 4 shows that all three components of stock performance are significantly related to internal CEO turnover.

First, turnover increases with poor industry-adjusted performance over the entire sample period and, particularly, in the latter 1998 to 2005 period. For the 1998 to 2005 subperiod, a one-standard deviation (38\%) decline in a firm's industry adjusted stock return is associated with an increase of $3.5 \%$ in the likelihood of CEO turnover. This sensitivity appears to be greater than the sensitivities reported in Murphy (1999) for various subperiods between 1970 and 1995. This is particularly interesting given that Murphy (1999) finds that turnover is not related to industry-adjusted performance between 1990 and 1995.

Second, CEO turnover is also related to poor industry performance. Again, the relation appears to be driven by the second subperiod. For the 1998 to 2005 subperiod, a one-standard 
deviation $(22.5 \%)$ decline in industry performance is associated with a $2.1 \%$ increase in the likelihood of CEO turnover.

Third, lower overall market performance, as measured by the return on the S\&P 500 index, is also associated with a higher likelihood of internal CEO turnover. For the full sample period, a one-standard deviation (17\%) decline in the S\&P 500 index is associated with a significant increase of $2.2 \%$ in the probability of internal CEO turnover. This relation is driven by the second subperiod. There is no statistical relation between market performance and CEO turnover in the first sub-period (1992 to 1997). In contrast, in the later period (1998 to 2005), a one-standard deviation (18\%) decline in the S\&P 500 index corresponds to an increase of $2.9 \%$ in the probability of CEO turnover.

These results indicate that the relation between internal CEO turnover and overall stock market performance appears to have intensified after 1997. All three sensitivities to stock performance $-3.5 \%, 2.1 \%$, and $2.9 \%$, respectively, for one standard deviation changes in industry-adjusted, industry, and market performance - are economically meaningful relative to average internal turnover of $12.83 \%$ from 1998 to 2005.

The second set of regressions in table 4 includes the change in return on assets (ROA) in addition to the stock return variables. The results are qualitatively unchanged. The change in ROA is marginally significant during the full sample period from 1992 to 2004 but it is not statistically significant in the sub-period regressions. While the estimate is statistically significant, a one standard deviation increase in the change in ROA is associated with only a 0.7 percent increase in the likelihood of CEO turnover.

In table 5, we add one year of lagged performance variables to the regressions. The first set of regressions excludes the change in ROA while the second set includes the change in ROA. 
Consistent with the results in table 4 , table 5 suggests that boards are sensitive to all three types of stock performance over the entire sample period and increasingly sensitive to all three measures in the later period.

For the entire period, internal CEO turnover is significantly negatively related to industry-adjusted and overall market stock performance in the current year. Turnover also is significantly negatively related to industry-adjusted and industry performance stock performance in the previous year. Strangely, turnover is significantly positively related to the lagged return on the S\&P 500. (One possible explanation is that CEOs choose to leave after a year in which the market has done well.)

As in the previous results, the regressions in table 5 indicate that the turnoverperformance relations are driven by the later subperiod. During the later subperiod, internal CEO turnover is significantly related to industry-adjusted and industry stock performance in the current year and previous year. Turnover is negatively related to the overall market in the current year and positively related in the previous year.

The coefficients in the first set of regressions imply that a one-standard deviation decline in the S\&P 500 increases the likelihood of turnover by a total of $0.9 \%$ in the entire sample period and by $1.2 \%$ in the 1998 to 2005 subperiod (where we have added the current year and lagged year coefficients). A one-standard deviation decline in the firms' industry also increases the likelihood of turnover by a total of $1.3 \%$ over the entire sample period and by $1.9 \%$ in the 1998 to 2005 subperiod. Finally, a one-standard deviation decline in industry-adjusted performance increases the likelihood of turnover by $4.3 \%$ and $5.3 \%$, respectively, over the entire sample period and in the 1998 to 2005 subperiod. Again, the sensitivity to industry-adjusted 
performance for the 1998 to 2005 period appears to be greater than any of the sensitivities reported in Murphy (1999).

In the earlier subperiod, 1992 to 1997, contemporaneous and lagged industry-adjusted performance are significantly negative while lagged market performance is marginally significantly positive. The sum of the coefficients (lagged and contemporaneous) for each of the three stock performance measures is less negative in the earlier period than in the later period.

The regressions that include lagged change in ROA indicate that boards are sensitive to changes in operating performance in the later subperiods. However, a one standard deviation change in the change in ROA is associated with a smaller increase in CEO turnover than a one standard deviation change in the stock market performance. The differences in responsiveness to stock performance over the two subperiods remain.

Overall, the results in tables 4 and 5 suggest that since 1997, boards have been both more sensitive to poor performance and have responded more quickly to that poor performance. It is also worth noting that the economic magnitudes of the effect are large. For the 1998 to 2005 period, the coefficients imply that a CEO whose firm performs one standard deviation better than the industry has a 5.3\% lower likelihood of turnover while a CEO whose firm performs one standard deviation worse than the industry has a 5.3\% increase in the likelihood of turnover. From a base turnover level of $12.8 \%$, these imply likelihoods of $7.5 \%$ for the strong performer versus $18.1 \%$ for the poor performer. These are economically meaningful differences with $7.5 \%$ implying a tenure of 13.3 years and $18.1 \%$ implying a tenure of 5.5 years.

Table 6 repeats the table 5 probit regressions dividing the sample into two sets of firms: firms in the S\&P500 index and all other Fortune 500 firms. We do this for two reasons. First, many papers on executive compensation and corporate governance use the ExecuComp data set 
that includes only firms in various $\mathrm{S} \& \mathrm{P}$ indices. It is possible there is a selection bias in these firms. Second, investors may be more likely to pay attention to firms in the S\&P 500 index, and, if so, these firms would be more likely to be monitored by the press and institutional investors. Thus, the effect of stock market performance might be different for these firms (Bertrand and Mullanianathan, 2001).

The coefficient patterns are qualitatively similar for the two sets of firms. Turnover in both sets of firms is significantly related to industry-adjusted and market stock performance over the entire sample period. As in the sample overall, the relations are stronger in the more recent 1998 to 2005 period.

\section{B. Internal Turnover and Governance}

Recent work has suggested that differences in corporate governance may have real effects. Gompers, Ishii and Metrick (2003) find that differences in corporate governance are related to stock returns. Masulis, Wang, and Xie (2005) find that those differences in corporate governance are related to acquisition behavior.

In this section, we examine the relation between turnover, market and firm performance measures and governance. To do so, we use the GIM index developed by Gompers et al. (2003). They categorize 24 charter provisions, bylaw provisions, and other firm-level rules associated with corporate governance into five types: (1) Tactics for delaying hostile bidders, (2) voting rights, (3) director/officer protection, (4) other takeover defenses, and (5) state laws. Their overall index and the five component indices generally score one point for each provision that restricts shareholder rights or increases managerial power. Thus, a higher index score represents greater managerial power (weaker shareholder rights). 
We estimated turnover regressions that interact stock performance with the measure of governance. We used both a continuous measure of the GIM index as well as a dummy variable if the firm's GIM index was in the highest quintile. To the extent that the GIM index measures poor governance, one would expect the interaction terms to have positive coefficients.

Table 7 presents our results for regressions using the dummy variable for the highest GIM index quintile. For the sample overall and for each sub-period, the sum of the coefficients on the interaction terms for current year and lagged stock returns are insignificant for all three types of stock performance. In other words, governance does not appear to be related to turnover for the sum of the two coefficients.

The only way in which the GIM index interaction is significant is that turnover is significantly more sensitive to poor lagged industry-adjusted performance for the high GIM index firms during the overall sample period and in the 1998 to 2005 subperiod. The GIM index interaction for current year industry-adjusted performance is significantly positive in the 1998 to 2005 period. Again, in both the overall and 1998 to 2005 subperiods, the net effect of the interaction terms for the two years is to be insignificantly negatively related to industry-adjusted performance.

Although not reported in a table, our results also are qualitatively similar when we interact stock performance with the continuous measure of the GIM index.

Overall, then, we interpret these results as finding that the GIM measures of governance do not have an appreciable relation to or impact on CEO turnover. Our results are consistent with a contemporaneous paper by Bhagat and Bolton (2006) who also fail to find a significant effect on turnover when they interact governance and performance. 


\section{Forced Turnover}

Thus far, we have not distinguished between forced turnover and all other turnover. Jenter and Kanaan (2006) focus exclusively on forced turnover. As we do for all turnover, they find that forced turnover is related to the three different measures of performance. It is possible that our results are driven by the forced turnover in our sample. To examine whether this is the case and whether performance is related differently to forced turnover and standard internal turnover, we estimate multinomial logit (MNL) regressions.

We follow Huson, Parrino and Starks (2001) in classifying turnover as forced. (Jenter and Kanaan (2006) also use this classification scheme.) Specifically, if an article indicates that the $\mathrm{CEO}$ was fired, forced, or left following a policy disagreement or some other equivalent, then turnover is defined as forced. For the remaining announcements, succession is classified as forced when the CEO is under 60 and the first article reporting the announcement does not report the reason for the departure as involving death, poor health or the acceptance of another position elsewhere. Over the entire sample period, internal turnover is $11.79 \%$ per year. Forced turnover is $1.87 \%$ while unforced turnover is $9.80 \%{ }^{4}$ Identifiably forced turnover, therefore, is infrequent relative to all internal turnover.

We present the regression results in table 8 . The dependent variable categories in the MNL estimations are no turnover, unforced turnover, or forced turnover. The table reports the marginal effect of each regressor and the associated probability value (p-value) of the test that the marginal probability is equal to zero based on asymptotic standard errors.

The probability of forced turnover is significantly negatively related to the three components of firm performance - firm performance relative to the industry, the industry relative

\footnotetext{
${ }^{4}$ The sum does not add to $11.79 \%$ because 12 turnovers could not be classified as forced or unforced based on available information.
} 
to the market, and the overall market - in the current year and to industry-adjusted return in the previous year. The probability of unforced turnover is significantly negatively related to firm performance relative to the industry and the overall market in the current year, and to industry return and industry-adjusted return in the previous year.

Overall, then, both forced turnover and unforced turnover are sensitive to all three types of poor performance. This suggests that many unforced turnovers are not voluntary.

\section{External Turnover}

As discussed earlier, in addition to internal turnover, we examine external turnover.

Recall, non-standard or external turnover is turnover due to a merger or bankruptcy / delisting. We consider the CEO to have been turned over in a merger if his or her company is taken over by another company and he or she is not CEO of the combined company. We consider the CEO to have been turned over in a bankruptcy if he or she is no longer CEO of the bankrupt company. The incidence of external turnover is $3.1 \%$ per year over the sample period.

Table 9 reports probit regressions of the probability of external turnover as a function of stock market performance and operating performance. As in tables 4 and 5, we report the results with and without the change in operating performance. We do not include current year performance because firms are taken over or delisted in the current year.

The results in table 9 show that external turnover is not related to any of the three measures of stock performance over the entire sample period when we exclude the change in operating performance. When we include the change in operating performance, turnover is negatively related to industry performance relative to the market and positively related to the change in operating performance. Even in this case, the marginal probabilities are economically 
small. For example, a one standard deviation decline in industry performance over the sample period (1992 to 2004) increases the probability of an external turnover by $0.08 \%$.

The insignificant results for external turnover and performance suggest that, on average, takeovers during this period were not disciplinary in nature.

\section{Summary and Implications}

In this paper, we examine the extent of and determinants of internal and external CEO turnover for a sample of large U.S. companies from 1992 to 2005. Total turnover, the sum of internal and external turnover, is about 14.9\% from 1992 to 2005, implying an average CEO

tenure of less than seven years. In the more recent period from 1998 to 2005, total CEO turnover increases to $16.5 \%$, implying an average tenure of approximately six years.

Internal CEO turnover that is associated with a company's board of directors is significantly related to three components of firm performance - performance relative to the industry, industry performance relative to the overall market, and the performance of the overall market. These relations intensify after 1997 in that from 1998 onward internal turnover is more strongly related to all three measures of performance in the contemporaneous year. These results remain even after controlling for operating performance and governance measures.

We also examine the likelihood of forced turnover, unforced turnover and no turnover using MNL regressions. Both forced turnover and unforced turnover are sensitive to all three types of poor performance.

Finally, external turnover is not related to any of the three measures of performance industry-adjusted, industry and market performance - over the entire sample period.

We believe our results have a number of implications. 
First, the results suggest an evolving role for boards. In a sample from the 1980s, Morck, Shleifer and Vishny (1989) find that internal turnover is related to industry-adjusted performance while external turnover from hostile takeovers is related to industry performance. They interpret this as indicating boards respond well to poor performance relative to the industry, but do not respond well to poor industry performance. The external takeover market becomes active in reaction to poor industry performance and a need for restructuring.

Our results suggest that boards now respond not only to poor performance relative to the industry, but also to poor industry and to poor market performance. To the extent that internal turnover has increased, boards also appear to monitor more frequently or aggressively. One interpretation of these results is that boards - possibly encouraged by large shareholders perform both the role they played in the 1980s and the role that hostile takeovers played then.

It is worth repeating that the results indicate that boards do not index CEO turnover to the industry or the market. This is noteworthy in light of criticisms of boards for not indexing CEO pay to the industry or the market. Bebchuk and Fried (2003) interpret the lack of indexing of pay as a failure of governance. Our results on turnover in conjunction with those in Morck et al. (1989) for the earlier period provide an alternative explanation. When an industry or the overall economy performs poorly, it is sometimes efficient for the board to bring on a new CEO to respond to the new industry or market conditions.

Second, the CEO job is more precarious than has been previously recognized. When external takeovers are included, the average tenure of a CEO has declined to as little as six years in the most recent 1998 to 2005 period. This is substantially shorter than the average tenures reported in previous work for the 1970s, 1980s, and 1990s. 
The shorter expected tenure coincides with the well-documented increase in annual CEO pay over the same period. For an individual CEO, therefore, the shorter tenure partially offsets the increase in pay. For example, the annual pay of S\&P 500 CEOs roughly doubled in real terms from the 1992 - 1997 period to the 1998 - 2004 period. Our estimates indicate that the total pay of an individual CEO over his entire expected term increased by less than this because the expected tenure at the higher pay declined by roughly $1 / 4$ to $1 / 3$.

This calculation would be inaccurate if severance agreements around internal turnover and takeovers are both large and have increased over time. If, instead, the severance agreements are small, then they do not have much of an effect on a CEOs total pay. And if they have remained the same over time, then they increase pay by similar amounts in both periods. Yermack (2006) studies separation payments made when Fortune 500 CEOs leave their firms. While more than half of the CEOs in his sample receive compensation upon leaving, he concludes that the mean payments are "modest," averaging less than one year's compensation. He does not study whether these payments have changed over time. Hartzell, Ofek and Yermack (2004) study benefits obtained by target company CEOs in acquisitions. Excluding gains on the shares and options the CEOs already hold, Hartzell et al. find that the CEOs receive an average of roughly $\$ 3$ million (and a median that appears to be roughly $\$ 1$ million) in benefits. They do not study whether these payments have changed over time.

Overall, then, the severance payments in Yermack (2006) and Hartzell et al. (2004) do not seem large enough to alter the conclusion that the job of CEO has become riskier and that the shorter expected tenures of CEOs partially offset the increases in CEO pay.

Third, the shorter expected CEO tenures and sensitivity of those tenures to stock performance have implications for the measurement of CEO pay. The shorter expected tenures 
suggest that the estimates of CEO pay used in most compensation studies are overstated. Most such studies use Standard and Poor's ExecuComp data. ExecuComp estimates the value of options grants using Black-Scholes. While option grants typically have a ten-year life, ExecuComp uses a seven-year life because "executives rarely wait until the expiration date to exercise their options." This adjustment assumes that CEOs will remain with the company for at least seven years. If a CEO has an expected initial tenure of six years, the ExecuComp assumption will tend to overstate the value of option grants every year of the CEO's tenure with the overstatement increasing each year. This assumes that CEOs forfeit unvested options and / or must exercise vested options when they leave the company. For internal turnover, Yermack (2006) finds that this tends to be the default policy for most companies and companies deviate from those policies in only $16 \%$ of the internal turnovers he studies. The reasonableness of the assumption is less clear and less well-documented in the (less frequent) instances of external takeovers.

The sensitivity of turnover to performance implies that both the vesting and life of stock options are not independent of performance. The options of CEOs of companies that perform poorly will both have a shorter effective life and will be worth less. The Black-Scholes methodology does not account for these correlations. This, in turn, implies that a proper stock option valuation - e.g., using a binomial tree approach - would incorporate these correlations.

Finally, shorter CEO tenures, the greater sensitivity to stock performance, as well as higher CEO pay may have created a greater incentive for CEOs to engage in earnings management or manipulation. 


\section{References}

Bebchuk, Lucian and Jesse Fried, "Managerial Power and Rent Extraction in the Design of Executive Compensation," University of Chicago Law Review 69, 751-846.

Bebchuk, L. and Y. Grinstein, 2005, The Growth of U.S. Executive Pay, Oxford Review of Economic Policy 21, 283-303.

Bertrand, Marian and Sendhil Mullainathan, 2001, Are CEOs rewarded for luck? The ones without principles are, Quarterly Journal of Economics 116, 901-932.

Bhagat, S. and B. Bolton, 2006, Corporate Governance And Firm Performance, working paper, University of Colorado at Boulder.

Fahlenbrack, R., 2004, Founder-CEOs and Stock Market Performance, Working paper, The Wharton School.

Garvey, G. and T. Milbourn, 2006, Asymmetric benchmarking in compensation: Executives are rewarded for good luck but not penalized for bad, Journal of Financial Economics.

Gillan, S., J. Hartzell, and R. Parrino, 2005, Explicit vs. Implicit Contracts: Evidence from CEO Employment Agreements, working paper, University of Texas at Austin.

Gompers, Paul A., Joy L. Ishii, and Andrew Metrick, 2003, Corporate governance and equity prices, Quarterly Journal of Economics 118 (1): 107-155.

Grossman, S. and O. Hart, 1982, Corporate Financial Structure and Managerial Incentives, in J.J. McCall, ed. The Economics of Information and Uncertainty (Chicago: University of Chicago Press), 107-140.

Hartzell, J., E. Ofek, and D. Yermack, 2004, What's in it for me? CEOs whose firms are acquired, Review of Financial Studies 17, 37-61.

Huson, M., Parrino, R., and Starks, L., 2001, "Internal Monitoring Mechanisms and CEO Turnover: A Long Term Perspective.” Journal of Finance 56, 2265-2297.

Jensen, M., K. Murphy, and E. Wruck, 2004, CEO Pay . . . and How to Fix It, Working paper, Harvard Business School.

Jensen, M. 1986, Agency Costs of Free Cash Flow, Corporate Finance, and Takeovers, American Economic Review 76, 323-329.

Jenter, D. and F. Kanaan, 2005, Industry Cycles, CEO Turnover, and the Relative Performance Evaluation, Working paper, MIT. 
Kaplan, S. 1989. "The Effects of Management Buyouts on Operations and Value." Journal of Financial Economics 24, 217-254.

Khurana, R. 2002, Searching for a corporate savior: The Irrational Quest for Charismatic CEOs. Princeton University Press.

Masulis, R., C. Wang, and F. Xei, 2005, Corporate Governance and Acquirer Returns, working paper, Vanderbilt Uinversity.

Mikkelson and Partch, "The Decline of Takeovers and Disciplinary Managerial Turnover," with Megan Partch, Journal of Financial Economics 44, 205-228

Morck, R., A. Shleifer, and R. Vishny, 1989, Alternative mechanisms for corporate control, American Economic Review.

Murphy, Kevin J. 1999. "Executive Compensation.” In O. Ashenfelter and D. Card (eds.), Handbook of Labor Economics. Volume 3, North Holland, pp. 2485-2525.

Murphy, Kevin J. and Zabonjik, 2004, Managerial Capital and the Market for CEOs, working paper, USC.

Rusticus, T., 2006, Executive Severance Agreements, working paper, Wharton School, University of Pennsylvania.

Stulz, R., 1990, Managerial Discretion and Optimal Financing Policies, Journal of Financial Economics 26, 3-28.

Yermack, D., 2005, Golden Handshakes: Separation Pay for Retired and Dismissed CEOs, working paper, NYU. 


\section{Table 1: Sample characteristics}

Selected firm characteristics for sample firms. The sample includes Fortune 500 firms between 1992 and year-end 2005. Firm value equals the sum of the market value of equity, total long-term debt and the carrying value of preferred stock. EBITDA/total assets is the ratio of EBITDA to average total book assets. Annual stock return is the percentage change in the firm's stock price at fiscal year-end. Change in ROA equals the change in the ratio of the EBITDA to average total book assets. Market-to-book equals the ratio of firm value to average total book assets. Sales growth is the percentage change in annual sales. $R \& D / S a l e s$ is the ratio of $R \& D$ expenditures to sales. (Missing values of R\&D are set equal to zero.) The quick ratio is the ratio of cash, marketable securities and account receivables to total current liabilities. The current ratio is the ratio of total current assets to total current liabilities. The modified Z-score equals the sum of 3.3EBIT, sales, 1.4Retained earnings, and 1.2working capital divided by total assets. The Kaplan-Zingales index is calculated following Lamont, Polk, and Saá-Requejo (2001). Sample statistics are for firm averages.

\begin{tabular}{|c|c|c|c|c|c|c|}
\hline Variable & $\mathrm{N}$ & Mean & Median & Std. dev. & Minimum & Maximum \\
\hline \multicolumn{7}{|l|}{ Size } \\
\hline Total assets & 1,014 & 18,998 & 3,919 & 56,757 & 155 & 722,905 \\
\hline Sales & 1,014 & 7,520 & 3,911 & 13,060 & 209 & 172,847 \\
\hline Firm value & 1,012 & 15,950 & 4,572 & 41,732 & 43 & 609,466 \\
\hline \multicolumn{7}{|l|}{ Profitability } \\
\hline EBITDA/total assets & 1,005 & 0.1371 & 0.1311 & 0.0738 & -0.0384 & 0.4900 \\
\hline Annual stock return & 1,011 & 0.0791 & 0.0693 & 0.1761 & -0.7871 & 1.3913 \\
\hline Change in ROA & 997 & -0.0132 & -0.0087 & 0.0257 & -0.2104 & 0.1391 \\
\hline \multicolumn{7}{|l|}{ Growth Opportunities } \\
\hline Market-to-book & 1,012 & 1.2575 & 1.0133 & 0.8706 & 0.1157 & 5.8105 \\
\hline Sales growth & 1,009 & 0.1050 & 0.0755 & 0.1474 & -0.4773 & 1.3666 \\
\hline R\&D/sales & 1,018 & 0.0152 & 0.0000 & 0.0343 & 0.0000 & 0.2551 \\
\hline \multicolumn{7}{|l|}{ Liquidity } \\
\hline Quick ratio & 1,009 & 0.4238 & 0.1880 & 0.7662 & 0.0017 & 5.3435 \\
\hline Current ratio & 1,009 & 1.9500 & 1.4944 & 2.0829 & 0.3359 & 15.4947 \\
\hline \multicolumn{7}{|l|}{ Financial constraints } \\
\hline Modified Z-score & 1,011 & 1.8811 & 1.8118 & 1.1609 & -0.3841 & 5.7507 \\
\hline Kaplan-Zingales index & 993 & -2.6327 & 0.2001 & 8.3359 & -52.0871 & 5.4286 \\
\hline
\end{tabular}




\section{Table 2. CEO Turnover}

CEO turnovers in publicly traded Fortune 500 companies between 1992 and year-end 2005. Total turnover is all CEO turnover including turnover due to mergers and acquisitions and delistings from a major stock exchange.

Standard turnover excludes turnover due to mergers and acquisitions and delistings from a major stock exchange. Data are from annual Fortune 500 lists, 10-K filings, proxy statements, Dun and Bradstreet's Million Dollar Directory and the Wall Street Journal. Year denotes the fiscal year-end for the sales data on which Fortune ranks firms. (i.e., 1992 corresponds to the 1993 April/May Fortune list.)

\begin{tabular}{c|c|cc|cc}
\hline & & \multicolumn{2}{|c|}{ Total Turnover } & \multicolumn{2}{c}{ Standard Turnover } \\
Year & $\begin{array}{c}\text { Number of } \\
\text { firms }\end{array}$ & Number & Percent & Number & Percent \\
\hline 1992 & 483 & 58 & $12.01 \%$ & 57 & $11.80 \%$ \\
1993 & 508 & 61 & 12.01 & 54 & 10.63 \\
1994 & 753 & 65 & 8.63 & 57 & 7.57 \\
1995 & 768 & 114 & 14.84 & 94 & 12.24 \\
1996 & 761 & 102 & 13.40 & 81 & 10.64 \\
1997 & 759 & 112 & 14.76 & 73 & 9.62 \\
1998 & 746 & 126 & 16.89 & 92 & 12.33 \\
1999 & 738 & 146 & 19.78 & 104 & 14.09 \\
2000 & 728 & 182 & 25.00 & 141 & 19.37 \\
2001 & 707 & 93 & 13.15 & 66 & 9.34 \\
2002 & 696 & 127 & 18.25 & 109 & 15.66 \\
2003 & 692 & 44 & 6.36 & 35 & 11.58 \\
2004 & 708 & 96 & 13.56 & 82 & 14.87 \\
2005 & 706 & 127 & 17.99 & 105 & $11.79 \%$ \\
& & & & & 10.32 \\
Total & 9,753 & 1,453 & $14.90 \%$ & 1,150 & 12.83 \\
$1992-1997$ & 4,032 & 512 & 12.70 & 416 & 734 \\
$1998-2005$ & 5,721 & 941 & 16.45 & &
\end{tabular}


Figure 1
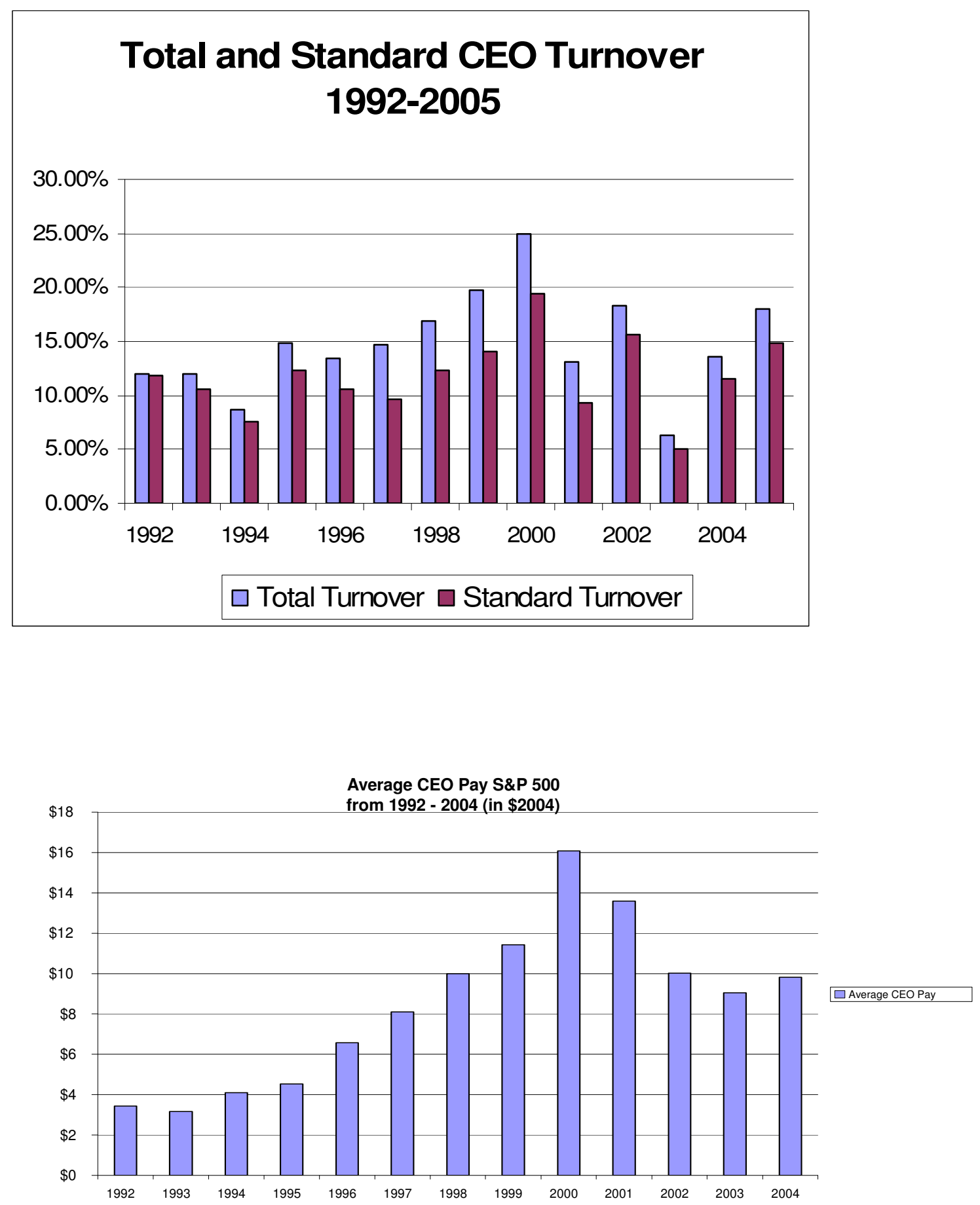


\section{Table 3. CEO turnover}

Number and percent of firms experiencing no turnover over a five-year period. Turnover is measured using total turnover. Total turnover is all CEO turnover including turnover due to mergers and acquisitions and delistings from a major stock exchange.

\begin{tabular}{l|c} 
Year & 1992 \\
\hline Number of firms & 483 \\
Number of firms experiencing no turnover between 1992 and 1997 & 169 \\
Percent of firms experiencing no turnover between 1992 and 1997 & $34.99 \%$ \\
Year & 1998 \\
\hline Number of firms & 746 \\
Number of firms experiencing no turnover between 1998 and 2003 & 180 \\
Percent of firms experiencing no turnover between 1998 and 2003 & $24.13 \%$
\end{tabular}


Table 4. Probit regressions of the probability of internal CEO turnover on performance

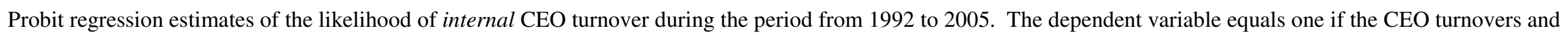
zero otherwise. $\triangle$ Prob measures the change in the probability of CEO turnover per unit change in the relevant explanatory variables. For indicator variables, the coefficient represents the change in the probability associated with moving the indicator from 0 to 1 . Models are estimated with robust standard errors to control for

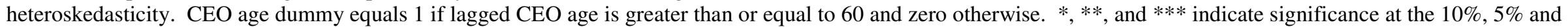
$1 \%$ levels, respectively. p-values are in parentheses.

\begin{tabular}{|c|c|c|c|c|c|c|}
\hline Variable & $\begin{array}{c}\text { Full sample } \\
1992-2005 \\
\Delta \text { Prob } \\
\text { (p-value) }\end{array}$ & $\begin{array}{c}\text { 1992-1997 } \\
\Delta \text { Prob } \\
\text { (p-value })\end{array}$ & $\begin{array}{c}1998-2005 \\
\Delta \text { Prob } \\
(\mathrm{p} \text {-value })\end{array}$ & $\begin{array}{c}\text { Model } 2 \\
1992-2004 \\
\Delta \text { Prob } \\
\text { (p-value) }\end{array}$ & $\begin{array}{c}\text { 1992-1997 } \\
\Delta \text { Prob } \\
(\mathrm{p} \text {-value })\end{array}$ & $\begin{array}{c}1998-2004 \\
\Delta \text { Prob } \\
(\mathrm{p}-\text {-value })\end{array}$ \\
\hline Return on S\&P 500 & $\begin{array}{l}-0.1253 * * * \\
(0.000)\end{array}$ & $\begin{array}{l}0.0208 \\
(0.530)\end{array}$ & $\begin{array}{l}-0.1664 * * * \\
(0.000)\end{array}$ & $\begin{array}{l}-0.1102 * * * \\
(0.000)\end{array}$ & $\begin{array}{c}0.0189 \\
(0.575)\end{array}$ & $\begin{array}{l}-0.1528 * * * \\
(0.000)\end{array}$ \\
\hline $\begin{array}{l}\text { Industry return - return } \\
\text { on S\&P500 }\end{array}$ & $\begin{array}{l}-0.0553 * * * \\
(0.003)\end{array}$ & $\begin{array}{r}0.0221 \\
(0.480)\end{array}$ & $\begin{array}{l}-0.0925 * * * \\
(0.000)\end{array}$ & $\begin{array}{l}-0.0479 * * * \\
(0.000)\end{array}$ & $\begin{array}{c}0.0299 \\
(0.341)\end{array}$ & $\begin{array}{l}-0.0868 * * * \\
(0.000)\end{array}$ \\
\hline $\begin{array}{l}\text { Industry-adjusted stock } \\
\text { return }\end{array}$ & $\begin{array}{l}-0.0690 * * * \\
(0.000)\end{array}$ & $\begin{array}{l}-0.0329 * * \\
(0.030)\end{array}$ & $\begin{array}{l}-0.0914 * * * \\
(0.000)\end{array}$ & $\begin{array}{l}-0.0645^{* * * *} \\
(0.000)\end{array}$ & $\begin{array}{l}-0.0288 * \\
(0.067)\end{array}$ & $\begin{array}{l}-0.0896 * * * \\
(0.000)\end{array}$ \\
\hline Change in ROA & - & - & - & $\begin{array}{l}-0.1535^{*} \\
(0.057)\end{array}$ & $\begin{array}{l}-0.1217 \\
(0.288)\end{array}$ & $\begin{array}{l}-0.1639 \\
(0.151)\end{array}$ \\
\hline CEO age dummy & $\begin{array}{l}0.1541^{* * * *} \\
(0.000)\end{array}$ & $\begin{array}{l}0.1441 * * * \\
(0.000)\end{array}$ & $\begin{array}{l}0.1640 * * * \\
(0.000)\end{array}$ & $\begin{array}{l}0.1488 * * * \\
(0.000)\end{array}$ & $\begin{array}{l}0.1452 * * * \\
(0.000)\end{array}$ & $\begin{array}{l}0.1544 * * * \\
(0.000)\end{array}$ \\
\hline Number of obs & 9,370 & 4,132 & 5,238 & 8,564 & 4,057 & 4,507 \\
\hline Pseudo $\mathrm{R}^{2}$ & 0.0746 & 0.0737 & 0.0764 & 0.0745 & 0.0744 & 0.0773 \\
\hline
\end{tabular}




\section{Table 5. Probit regressions of the probability of internal CEO turnover on performance and lagged performance}

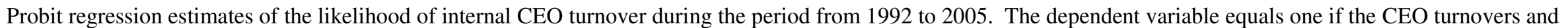
zero otherwise. $\triangle$ Prob measures the change in the probability of CEO turnover per unit change in the relevant explanatory variables. For indicator variables, the coefficient represents the change in the probability associated with moving the indicator from 0 to 1 . Models are estimated with robust standard errors to control for

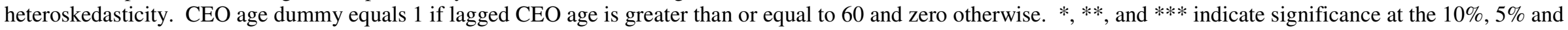
$1 \%$ levels, respectively. p-values are in parentheses.

\begin{tabular}{|c|c|c|c|c|c|c|}
\hline Variable & $\begin{array}{c}\text { Full sample } \\
1992-2005 \\
\Delta \text { Prob } \\
\text { (p-value) }\end{array}$ & $\begin{array}{c}1992-1997 \\
\Delta \text { Prob } \\
\text { (p-value) }\end{array}$ & $\begin{array}{c}1998-2005 \\
\Delta \text { Prob } \\
(\mathrm{p} \text {-value })\end{array}$ & $\begin{array}{c}\text { Model } 2 \\
1992-2004 \\
\Delta \text { Prob } \\
\text { (p-value) }\end{array}$ & $\begin{array}{c}\text { 1992-1997 } \\
\Delta \text { Prob } \\
\text { (p-value) }\end{array}$ & $\begin{array}{c}1998-2004 \\
\Delta \text { Prob } \\
\text { (p-value) }\end{array}$ \\
\hline Return on S\&P 500 & $\begin{array}{l}-0.1447 * * * \\
(0.000)\end{array}$ & $\begin{array}{c}0.0259 \\
(0.471)\end{array}$ & $\begin{array}{l}-0.2101 * * * \\
(0.000)\end{array}$ & $\begin{array}{l}-0.1270 * * * \\
(0.000)\end{array}$ & $\begin{array}{c}0.0283 \\
(0.437)\end{array}$ & $\begin{array}{l}-0.1819 * * * \\
(0.000)\end{array}$ \\
\hline $\begin{array}{l}\text { Industry return - return on } \\
\text { S\&P500 }\end{array}$ & $\begin{array}{l}-0.0247 \\
(0.191)\end{array}$ & $\begin{array}{c}0.0364 \\
(0.248)\end{array}$ & $\begin{array}{l}-0.0468^{*} \\
(0.053)\end{array}$ & $\begin{array}{l}-0.0209 \\
(0.274)\end{array}$ & $\begin{array}{c}0.0461 \\
(0.168)\end{array}$ & $\begin{array}{l}-0.0377 \\
(0.126)\end{array}$ \\
\hline $\begin{array}{l}\text { Industry-adjusted stock } \\
\text { return }\end{array}$ & $\begin{array}{l}-0.0683 * * * \\
(0.000)\end{array}$ & $\begin{array}{l}-0.0317 * * \\
(0.032)\end{array}$ & $\begin{array}{l}-0.0899 * * * \\
(0.000)\end{array}$ & $\begin{array}{l}-0.0643 * * * \\
(0.000)\end{array}$ & $\begin{array}{l}-0.0322 * * \\
(0.039)\end{array}$ & $\begin{array}{l}-0.0832 * * * \\
(0.000)\end{array}$ \\
\hline Change in ROA & - & - & - & $\begin{array}{l}-0.1409 \\
(0.109)\end{array}$ & $\begin{array}{l}-0.0526 \\
(0.679)\end{array}$ & $\begin{array}{l}-0.2297^{*} \\
(0.062)\end{array}$ \\
\hline Lagged return on S\&P 500 & $\begin{array}{l}0.0886^{* * *} \\
(0.000)\end{array}$ & $\begin{array}{l}0.0593^{*} \\
(0.054)\end{array}$ & $\begin{array}{l}0.1418^{* * * *} \\
(0.000)\end{array}$ & $\begin{array}{l}0.0880 * * * \\
(0.000)\end{array}$ & $\begin{array}{c}0.0491 \\
(0.143)\end{array}$ & $\begin{array}{l}0.1454 * * * \\
(0.000)\end{array}$ \\
\hline $\begin{array}{l}\text { Lagged industry return - } \\
\text { return on S\&P500 }\end{array}$ & $\begin{array}{l}-0.0411 * * \\
(0.022)\end{array}$ & $\begin{array}{l}-0.0190 \\
(0.578)\end{array}$ & $\begin{array}{l}-0.0360^{*} \\
(0.099)\end{array}$ & $\begin{array}{l}-0.0352^{*} \\
(0.058)\end{array}$ & $\begin{array}{l}-0.0252 \\
(0.480)\end{array}$ & $\begin{array}{l}-0.0239 \\
(0.287)\end{array}$ \\
\hline $\begin{array}{l}\text { Lagged industry-adjusted } \\
\text { stock return }\end{array}$ & $\begin{array}{l}-0.0526 * * * \\
(0.000)\end{array}$ & $\begin{array}{l}-0.0603 * * * \\
(0.000)\end{array}$ & $\begin{array}{l}-0.0497 * * * \\
(0.000)\end{array}$ & $\begin{array}{l}-0.0547 * * * \\
(0.000)\end{array}$ & $\begin{array}{l}-0.0679 * * * \\
(0.000)\end{array}$ & $\begin{array}{l}-0.0456^{* * *} \\
(0.001)\end{array}$ \\
\hline Lagged change in ROA & - & - & - & $\begin{array}{l}-0.0173 \\
(0.772)\end{array}$ & $\begin{array}{l}0.1205^{*} \\
(0.092)\end{array}$ & $\begin{array}{l}-0.2183 * * \\
(0.048)\end{array}$ \\
\hline CEO age dummy & $\begin{array}{l}0.1504 * * * \\
(0.000)\end{array}$ & $\begin{array}{l}0.1417 * * * \\
(0.000)\end{array}$ & $\begin{array}{l}0.1585^{* * *} \\
(0.000)\end{array}$ & $\begin{array}{l}0.1451^{* * *} \\
(0.000)\end{array}$ & $\begin{array}{l}0.1382 * * * \\
(0.000)\end{array}$ & $\begin{array}{l}0.1497 * * * \\
(0.000)\end{array}$ \\
\hline Number of obs & 9,216 & 4,046 & 5,170 & 8,378 & 3,949 & 4,429 \\
\hline Pseudo $\mathrm{R}^{2}$ & 0.0852 & 0.0845 & 0.0892 & 0.0858 & 0.0854 & 0.0926 \\
\hline
\end{tabular}




\section{Table 6. Probit regressions of relation of internal CEO turnover and performance for Fortune 500 firms in and not in the S\&P 500 Index}

Probit regression estimates of the likelihood of internal CEO turnover for Fortune 500 firms during the period from 1992 to 2005 . Firms are divided into those in the S\&P 500 index and those not in the index. The dependent variable equals one if the CEO turnovers and zero otherwise. $\triangle$ Prob measures the change in the probability of CEO turnover per unit change in the relevant explanatory variables. For indicator variables, the coefficient represents the change in the probability associated with moving the indicator from 0 to 1 . Models are estimated with robust standard errors to control for heteroskedasticity. CEO age dummy equals 1 if lagged CEO age is greater than or equal to 60 and zero otherwise. *, **, and *** indicate significance at the $10 \%, 5 \%$ and $1 \%$ levels, respectively. p-values are in parentheses.

\begin{tabular}{|c|c|c|c|c|c|c|}
\hline \multirow[b]{2}{*}{ Variable } & \multicolumn{2}{|c|}{ Full Sample } & \multicolumn{2}{|c|}{$1992-1997$} & \multicolumn{2}{|c|}{$1998-2005$} \\
\hline & $\begin{array}{l}\text { In S\&P } 500 \\
\text { Index } \\
\Delta \text { Prob } \\
\text { (p-value) }\end{array}$ & $\begin{array}{c}\text { All other firms } \\
\begin{array}{c}\Delta \text { Prob } \\
(\mathrm{p} \text {-value })\end{array}\end{array}$ & $\begin{array}{l}\text { In S\&P } 500 \\
\text { Index } \\
\Delta \text { Prob } \\
\text { (p-value) }\end{array}$ & $\begin{array}{c}\text { All other firms } \\
\begin{array}{c}\Delta \text { Prob } \\
(\mathrm{p}-\mathrm{v} \text {-value })\end{array}\end{array}$ & $\begin{array}{l}\text { In S\&P } 500 \\
\text { Index } \\
\Delta \text { Prob } \\
\text { (p-value) }\end{array}$ & $\begin{array}{c}\text { All other firms } \\
\begin{array}{c}\Delta \text { Prob } \\
(\mathrm{p} \text {-value })\end{array}\end{array}$ \\
\hline Return on S\&P 500 & $\begin{array}{l}-0.1584 * * * \\
(0.000)\end{array}$ & $\begin{array}{l}-0.1323 * * * \\
(0.000)\end{array}$ & $\begin{array}{r}0.0319 \\
(0.488)\end{array}$ & $\begin{array}{c}0.0078 \\
(0.890)\end{array}$ & $\begin{array}{l}-0.2699 * * * \\
(0.000)\end{array}$ & $\begin{array}{l}-0.1377 * * * \\
(0.005)\end{array}$ \\
\hline $\begin{array}{l}\text { Industry return - return on } \\
\text { S\&P500 }\end{array}$ & $\begin{array}{l}-0.0172 \\
(0.485)\end{array}$ & $\begin{array}{l}-0.0377 \\
(0.202)\end{array}$ & $\begin{array}{l}0.0840 * * \\
(0.045)\end{array}$ & $\begin{array}{l}-0.0336 \\
(0.477)\end{array}$ & $\begin{array}{l}-0.0569^{*} \\
(0.069)\end{array}$ & $\begin{array}{l}-0.0422 \\
(0.267)\end{array}$ \\
\hline $\begin{array}{l}\text { Industry-adjusted stock } \\
\text { return }\end{array}$ & $\begin{array}{l}-0.0463 * * * \\
(0.002)\end{array}$ & $\begin{array}{l}-0.0876^{* * * *} \\
(0.000)\end{array}$ & $\begin{array}{r}0.0004 \\
(0.987)\end{array}$ & $\begin{array}{l}-0.0580^{* * *} \\
(0.004)\end{array}$ & $\begin{array}{l}-0.0735^{* * *} \\
(0.000)\end{array}$ & $\begin{array}{l}-0.1061 * * * \\
(0.000)\end{array}$ \\
\hline Lagged return on S\&P 500 & $\begin{array}{l}0.1127 * * * \\
(0.000)\end{array}$ & $\begin{array}{c}0.0492 \\
(0.139)\end{array}$ & $\begin{array}{r}0.0549 \\
(0.170)\end{array}$ & $\begin{array}{l}0.0820 * \\
(0.083)\end{array}$ & $\begin{array}{l}0.1992 * * * \\
(0.000)\end{array}$ & $\begin{array}{r}0.0551 \\
(0.247)\end{array}$ \\
\hline $\begin{array}{l}\text { Lagged industry return - } \\
\text { return on S\&P500 }\end{array}$ & $\begin{array}{l}-0.0352 \\
(0.142)\end{array}$ & $\begin{array}{l}-0.0418 \\
(0.122)\end{array}$ & $\begin{array}{l}-0.0258 \\
(0.585)\end{array}$ & $\begin{array}{l}-0.0040 \\
(0.935)\end{array}$ & $\begin{array}{l}-0.0222 \\
(0.436)\end{array}$ & $\begin{array}{l}-0.0483 \\
(0.149)\end{array}$ \\
\hline $\begin{array}{l}\text { Lagged industry-adjusted } \\
\text { stock return }\end{array}$ & $\begin{array}{l}-0.0467 * * * \\
(0.001)\end{array}$ & $\begin{array}{l}-0.0598 * * * \\
(0.000)\end{array}$ & $\begin{array}{l}-0.0744 * * * \\
(0.002)\end{array}$ & $\begin{array}{l}-0.0498^{* *} \\
(0.019)\end{array}$ & $\begin{array}{l}-0.0372 * * \\
(0.039)\end{array}$ & $\begin{array}{l}-0.0655^{* * *} \\
(0.000)\end{array}$ \\
\hline CEO age dummy & $\begin{array}{l}0.1728 * * * \\
(0.000)\end{array}$ & $\begin{array}{l}0.1216^{* * * *} \\
(0.000)\end{array}$ & $\begin{array}{l}0.1806^{* * * *} \\
(0.000)\end{array}$ & $\begin{array}{l}0.0819 * * * \\
(0.000)\end{array}$ & $\begin{array}{l}0.1675^{* * *} \\
(0.000)\end{array}$ & $\begin{array}{l}0.1472 * * * \\
(0.000)\end{array}$ \\
\hline Number of obs & 5,144 & 4,072 & 2,398 & 1,648 & 2,746 & 2,424 \\
\hline Pseudo $\mathrm{R}^{2}$ & 0.0979 & 0.0750 & 0.1129 & 0.0585 & 0.1014 & 0.0802 \\
\hline
\end{tabular}




\section{Table 7. Probit regressions of internal CEO turnover for Fortune 500 firms on performance and governance}

Probit regression estimates of the likelihood of internal CEO turnover for Fortune 500 firms during the period 1992 to 2005. The dependent variable equals one if the CEO turnovers and zero otherwise. $\triangle$ Prob measures the change in the probability of CEO turnover per unit change in the relevant explanatory variables. For indicator variables, the coefficient represents the change in the probability associated with moving the indicator from 0 to 1 . Models are estimated with robust standard errors to control for heteroskedasticity. CEO age dummy equals 1 if lagged CEO age is greater than or equal to 60 and zero otherwise. $*, * *$, and $* * *$ indicate significance at the $10 \%, 5 \%$ and $1 \%$ levels, respectively. p-values are in parentheses.

\begin{tabular}{|c|c|c|c|}
\hline Variable & $\begin{array}{c}\text { Full Sample } \\
\Delta \text { Prob } \\
\text { (p-value) }\end{array}$ & $\begin{array}{c}1992-1997 \\
\Delta \text { Prob } \\
\text { (p-value) }\end{array}$ & $\begin{array}{c}1998-2005 \\
\Delta \text { Prob } \\
\text { (p-value) }\end{array}$ \\
\hline Return on S\&P 500 & $\begin{array}{l}-0.1448 * * * \\
(0.000)\end{array}$ & $\begin{array}{r}0.0040 \\
(0.922)\end{array}$ & $\begin{array}{l}-0.2103 * * * \\
(0.000)\end{array}$ \\
\hline $\begin{array}{l}\text { Industry return - return } \\
\text { on S\&P500 }\end{array}$ & $\begin{array}{l}-0.0152 \\
(0.487)\end{array}$ & $\begin{array}{c}0.0341 \\
(0.348)\end{array}$ & $\begin{array}{l}-0.0341 \\
(0.225)\end{array}$ \\
\hline $\begin{array}{l}\text { Industry-adjusted stock } \\
\text { return }\end{array}$ & $\begin{array}{l}-0.0762 * * * \\
(0.000)\end{array}$ & $\begin{array}{l}-0.0369 * * \\
(0.023)\end{array}$ & $\begin{array}{l}-0.1012 * * * \\
(0.000)\end{array}$ \\
\hline $\begin{array}{l}\text { Lagged return on S\&P } \\
500\end{array}$ & $\begin{array}{l}0.0951 * * * \\
(0.000)\end{array}$ & $\begin{array}{l}0.0662 * \\
(0.057)\end{array}$ & $\begin{array}{l}0.1463 * * * \\
(0.000)\end{array}$ \\
\hline $\begin{array}{l}\text { Lagged industry return - } \\
\text { return on S\&P500 }\end{array}$ & $\begin{array}{l}-0.0500^{* *} \\
(0.017)\end{array}$ & $\begin{array}{l}-0.0268 \\
(0.502)\end{array}$ & $\begin{array}{l}-0.0461 * \\
(0.072)\end{array}$ \\
\hline $\begin{array}{l}\text { Lagged industry-adjusted } \\
\text { stock return }\end{array}$ & $\begin{array}{l}-0.0508 * * * \\
(0.000)\end{array}$ & $\begin{array}{l}-0.0761 * * * \\
(0.000)\end{array}$ & $\begin{array}{l}-0.0364 * * \\
(0.016)\end{array}$ \\
\hline G index & $\begin{array}{r}0.0012 \\
(0.461)\end{array}$ & $\begin{array}{c}0.0026 \\
(0.207)\end{array}$ & $\begin{array}{l}-0.0001 \\
(0.696)\end{array}$ \\
\hline CEO age dummy & $\begin{array}{l}0.1474 * * * \\
(0.000)\end{array}$ & $\begin{array}{l}0.1411^{* * *} \\
(0.000)\end{array}$ & $\begin{array}{l}0.1559 * * * \\
(0.000)\end{array}$ \\
\hline High G Index dummy & $\begin{array}{r}0.1639 \\
(0.384)\end{array}$ & $\begin{array}{r}0.1122 \\
(0.630)\end{array}$ & $\begin{array}{r}0.2081 \\
(0.477)\end{array}$ \\
\hline \multicolumn{4}{|l|}{ High G Index dummy } \\
\hline$x($ Return on S\&P 500) & $\begin{array}{c}0.0924 \\
(0.140)\end{array}$ & $\begin{array}{c}0.0923 \\
(0.381)\end{array}$ & $\begin{array}{r}0.1307 \\
(0.157)\end{array}$ \\
\hline $\begin{array}{l}x(\text { Industry return }- \text { return } \\
\text { on S\&P500) }\end{array}$ & $\begin{array}{c}0.0234 \\
(0.672)\end{array}$ & $\begin{array}{c}0.0693 \\
(0.401)\end{array}$ & $\begin{array}{l}-0.0041 \\
(0.958)\end{array}$ \\
\hline $\begin{array}{l}x \text { (Industry-adjusted stock } \\
\text { return) }\end{array}$ & $\begin{array}{c}0.0513 \\
(0.124)\end{array}$ & $\begin{array}{l}-0.0264 \\
(0.613)\end{array}$ & $\begin{array}{l}0.1070^{* *} \\
(0.020)\end{array}$ \\
\hline $\begin{array}{l}x(\text { Lagged return on } S \& P \\
500)\end{array}$ & $\begin{array}{l}-0.0211 \\
(0.730)\end{array}$ & $\begin{array}{c}0.0166 \\
(0.845)\end{array}$ & $\begin{array}{l}-0.0674 \\
(0.466)\end{array}$ \\
\hline $\begin{array}{l}x(\text { Lagged industry return } \\
- \text { return on S\&P500) }\end{array}$ & $\begin{array}{c}0.0475 \\
(0.393)\end{array}$ & $\begin{array}{c}0.0539 \\
(0.538)\end{array}$ & $\begin{array}{r}0.0441 \\
(0.554)\end{array}$ \\
\hline $\begin{array}{l}x(\text { Lagged industry- } \\
\text { adjusted stock return) }\end{array}$ & $\begin{array}{l}-0.0859^{* *} \\
(0.020)\end{array}$ & $\begin{array}{c}0.0103 \\
(0.825)\end{array}$ & $\begin{array}{l}-0.1520^{* * * *} \\
(0.004)\end{array}$ \\
\hline$x(G$ index $)$ & $\begin{array}{l}-0.0106 \\
(0.303)\end{array}$ & $\begin{array}{l}-0.0087 \\
(0.501)\end{array}$ & $\begin{array}{l}-0.0118 \\
(0.457)\end{array}$ \\
\hline $\mathrm{x}(\mathrm{CEO}$ age dummy $)$ & $\begin{array}{c}0.0293 \\
(0.141)\end{array}$ & $\begin{array}{c}0.0232 \\
(0.368)\end{array}$ & $\begin{array}{c}0.0301 \\
(0.311)\end{array}$ \\
\hline Number of obs. & 7,717 & 3,722 & 3,995 \\
\hline Pseudo $\mathrm{R}^{2}$ & 0.0934 & 0.0945 & 0.0998 \\
\hline
\end{tabular}


Table 8. Multinominal logit regression estimates of the likelihood of no CEO turnover, unforced CEO turnover and forced CEO turnover for Fortune 500 firms.

Multinominal logit regression estimates of the likelihood of no CEO turnover, non-forced CEO turnover and forced CEO turnover for Fortune 500 firms during the period 1992 to 2005.. $\Delta$ Prob measures the change in the probability of the particular choice per unit change in the relevant explanatory variables. For indicator variables, the coefficient represents the change in the probability associated with moving the indicator from 0 to 1 . Models are estimated with robust standard errors to control for heteroskedasticity. CEO age dummy equals 1 if lagged CEO age is greater than or equal to 60 and zero otherwise. *, **, and *** indicate significance at the $10 \%, 5 \%$ and $1 \%$ levels, respectively. p-values are in parentheses.

\begin{tabular}{|c|c|c|c|}
\hline Variable & $\begin{array}{c}\text { No turnover } \\
\Delta \text { Prob } \\
\text { (p-value) }\end{array}$ & $\begin{array}{c}\text { Unforced CEO turnover } \\
\Delta \text { Prob } \\
(\mathrm{p} \text {-value })\end{array}$ & $\begin{array}{c}\text { Forced CEO turnover } \\
\qquad \text { Prob } \\
(\mathrm{p} \text {-value })\end{array}$ \\
\hline Return on S\&P 500 & $\begin{array}{l}0.1241^{* * * *} \\
(0.000)\end{array}$ & $\begin{array}{l}-0.0924 * * * \\
(0.000)\end{array}$ & $\begin{array}{l}-0.0316^{* * * *} \\
(0.000)\end{array}$ \\
\hline $\begin{array}{l}\text { Industry return - } \\
\text { return on } S \& P 500\end{array}$ & $\begin{array}{c}0.0217 \\
(0.182)\end{array}$ & $\begin{array}{l}-0.0023 \\
(0.882)\end{array}$ & $\begin{array}{l}-0.0194 * * * \\
(0.000)\end{array}$ \\
\hline $\begin{array}{l}\text { Industry-adjusted } \\
\text { stock return }\end{array}$ & $\begin{array}{l}0.0577 * * * \\
(0.0000)\end{array}$ & $\begin{array}{l}-0.0301 * * * \\
(0.000)\end{array}$ & $\begin{array}{l}-0.0276^{* * * *} \\
(0.000)\end{array}$ \\
\hline $\begin{array}{l}\text { Lagged return on S\&P } \\
500\end{array}$ & $\begin{array}{l}-0.0749 * * * \\
(0.000)\end{array}$ & $\begin{array}{l}0.0536 * * * \\
(0.002)\end{array}$ & $\begin{array}{l}0.0213 * * * \\
(0.002)\end{array}$ \\
\hline $\begin{array}{l}\text { Lagged industry return } \\
\text { - return on S\&P500 }\end{array}$ & $\begin{array}{l}0.0315^{* *} \\
(0.042)\end{array}$ & $\begin{array}{l}-0.0282^{*} \\
(0.055)\end{array}$ & $\begin{array}{l}-0.0032 \\
(0.521)\end{array}$ \\
\hline $\begin{array}{l}\text { Lagged industry- } \\
\text { adjusted stock return }\end{array}$ & $\begin{array}{l}0.0446^{* * *} \\
(0.000)\end{array}$ & $\begin{array}{l}-0.0335 * * * \\
(0.000)\end{array}$ & $\begin{array}{l}-0.0111^{* *} \\
(0.003)\end{array}$ \\
\hline CEO age dummy & $\begin{array}{l}-0.1520 * * * \\
(0.000)\end{array}$ & $\begin{array}{l}0.1590^{* * *} \\
(0.000)\end{array}$ & $\begin{array}{l}-0.0070 * * * \\
(0.000)\end{array}$ \\
\hline Pseudo $\mathrm{R}^{2}=0.1003$ & & & \\
\hline
\end{tabular}




\section{Table 9. Probit regressions of the probability of external CEO turnover on performance}

Probit regression estimates of the likelihood of external CEO turnover for Fortune 500 firms during the period 1992 to 2005 . The dependent variable equals one if the CEO turnovers and zero otherwise. $\triangle$ Prob measures the change in the probability of CEO turnover per unit change in the relevant explanatory variables. For indicator variables, the coefficient represents the change in the probability associated with moving the indicator from 0 to 1 . Models are estimated with robust standard errors to control for heteroskedasticity. CEO age dummy equals 1 if lagged CEO age is greater than or equal to 60 and zero otherwise. *,**, and *** indicate significance at the $10 \%, 5 \%$ and $1 \%$ levels, respectively. p-values are in parentheses.

\begin{tabular}{|c|c|c|c|c|c|c|}
\hline Variable & $\begin{array}{c}\text { Full sample } \\
\text { 1992-2005 } \\
\Delta \text { Prob } \\
\text { (p-value) }\end{array}$ & $\begin{array}{c}\text { 1992-1997 } \\
\Delta \text { Prob } \\
\text { (p-value) }\end{array}$ & $\begin{array}{c}1998-2005 \\
\Delta \text { Prob } \\
\text { (p-value) }\end{array}$ & $\begin{array}{c}\text { Model } 2 \\
\text { 1992-2004 } \\
\Delta \text { Prob } \\
\text { (p-value) }\end{array}$ & $\begin{array}{c}\text { 1992-1997 } \\
\Delta \text { Prob } \\
\text { (p-value) }\end{array}$ & $\begin{array}{c}1998-2004 \\
\Delta \text { Prob } \\
\text { (p-value) }\end{array}$ \\
\hline $\begin{array}{l}\text { Lagged return on } \mathrm{S} \& \mathrm{P} \\
500\end{array}$ & $\begin{array}{l}-0.0003 \\
(0.908)\end{array}$ & $\begin{array}{l}-0.0001 \\
(0.793)\end{array}$ & $\begin{array}{c}0.0015 \\
(0.673)\end{array}$ & $\begin{array}{l}-0.0014 \\
(0.440)\end{array}$ & $\begin{array}{l}-0.0020 \\
(0.555)\end{array}$ & $\begin{array}{r}0.0001 \\
(0.965)\end{array}$ \\
\hline $\begin{array}{l}\text { Lagged industry return - } \\
\text { return on S\&P500 }\end{array}$ & $\begin{array}{l}-0.0033 \\
(0.200)\end{array}$ & $\begin{array}{l}-0.0040 \\
(0.129)\end{array}$ & $\begin{array}{l}-0.0032 \\
(0.308)\end{array}$ & $\begin{array}{l}-0.044 * * \\
(0.026)\end{array}$ & $\begin{array}{l}-0.0040^{*} \\
(0.086)\end{array}$ & $\begin{array}{l}-0.0045^{*} \\
(0.083)\end{array}$ \\
\hline $\begin{array}{l}\text { Lagged industry- } \\
\text { adjusted stock return }\end{array}$ & $\begin{array}{l}-0.0019 \\
(0.399)\end{array}$ & $\begin{array}{l}-0.0011 \\
(0.556)\end{array}$ & $\begin{array}{l}-0.0024 \\
(0.471)\end{array}$ & $\begin{array}{l}-0.0020 \\
(0.258)\end{array}$ & $\begin{array}{l}-0.0014 \\
(0.354)\end{array}$ & $\begin{array}{l}-0.0027 \\
(0.316)\end{array}$ \\
\hline Lagged change in ROA & - & - & - & $\begin{array}{l}0.0249 * * \\
(0.026)\end{array}$ & $\begin{array}{l}0.0098 * * * \\
(0.007)\end{array}$ & $\begin{array}{l}0.0412 * \\
(0.078)\end{array}$ \\
\hline CEO age dummy & $\begin{array}{l}0.0022 * \\
(0.093)\end{array}$ & $\begin{array}{c}0.0000 \\
(0.964)\end{array}$ & $\begin{array}{l}0.0039^{*} \\
(0.065)\end{array}$ & $\begin{array}{l}0.0006 \\
(0.497)\end{array}$ & $\begin{array}{l}-0.0001 \\
(0.845)\end{array}$ & $\begin{array}{c}0.0016 \\
(0.338)\end{array}$ \\
\hline Number of obs & 8,181 & 3,668 & 4,513 & 7,520 & 3,595 & 3,925 \\
\hline Pseudo $\mathrm{R}^{2}$ & 0.0169 & 0.0227 & 0.0224 & 0.0457 & 0.0496 & 0.0491 \\
\hline
\end{tabular}

